\title{
Meat preparation techniques: results of the ISACamp population-based survey
}

\author{
Técnicas de preparo de carne: resultados da pesquisa de base \\ populacional ISACamp
}

Daniela de Assumpção (https://orcid.org/0000-0003-1813-996X) ${ }^{1}$

Marilisa Berti de Azevedo Barros (https://orcid.org/0000-0003-3974-195X) ${ }^{1}$

Regina Mara Fisberg (https://orcid.org/0000-0002-4490-9035) ${ }^{2}$

Semíramis Martins Álvares Domene (https://orcid.org/0000-0003-3003-2153) ${ }^{3}$
${ }^{1}$ Faculdades de Ciências Médicas, Universidade Estadual de Campinas. R. Tessália Vieira de Camargo 126, Cidade Universitária Zeferino Vaz. 13083-887 Campinas SP Brasil. danideassumpcao@ gmail.com

${ }^{2}$ Faculdade de Saúde Pública, Universidade de São Paulo. São Paulo SP Brasil.

${ }^{3}$ Departamento de Políticas Públicas e Saúde Coletiva, Universidade Federal de São Paulo. São Paulo SP Brasil.

\begin{abstract}
This article aims to identify meat preparation techniques according to sociodemographic variables and health-related behaviors. Cross-sectional population-based survey that used one 24-hour recall to identify the meat preparation techniques. We analyzed 3,376 24-hour recalls. The meat preparation techniques were classified as moist-heat (sauté, stew, boil; MH) or dry-heat (sauté, stew, boil; MH) and dry-heat (baking, grilling/barbecuing and frying; $D H)$. The prevalence of use was $39.0 \%$ for moist cooking, $32.7 \%$ for frying and $28.3 \%$ for baking/grilling. Women, the elderly and those from other municipalities/ states were more likely to use $\mathrm{MH}$ cooking. $\mathrm{MH}$ techniques were least prevalent among those of higher socioeconomic status. Among the techniques of DH cooking, women, the elderly and people with higher education and income were less likely to fry meats. Those born in Campinas and those with higher income, education, and those who ate fruits and vegetables on a higher weekly frequency were more likely to roast/grill meats. The results show the epidemiological profile associated with meat preparation techniques. Women, the elderly and those with lower education are more likely to use MH cooking techniques and less likely to fry meats. Those economically more favored are less likely to use MH techniques and frying, and more roasting/grilling.
\end{abstract}

Key words Meat, Cooking, Food Intake, Health Surveys
Resumo $O$ objetivo deste artigo é identificar as técnicas de preparo utilizadas em carnes, segundo variáveis sociodemográficas e de comportamentos relacionados à saúde. Trata-se de estudo transversal de base populacional que utilizou um Recordatório de 24 horas para identificar as técnicas de preparo de carnes. Foram analisados 3.376 recordatórios. As técnicas de preparo foram classificadas em cocção úmida (refogar, ensopar, fervura) $e$ cocção seca (assar, grelhar, fritar). As prevalencias de uso foram de 39,0\% para cocção úmida, 32,7\% para fritura e 28,3\% para assar/grelhar. A cocção úmida foi mais prevalente nas mulheres, idosos e nos naturais de outros municípios/Estados, e menos prevalente nos segmentos de melhor nivel socioeconômico. Das técnicas de cocção seca, a fritura foi menos utilizada por mulheres, idosos e por pessoas com maior nível de educação e renda. O assar/grelhar foram as técnicas mais aplicadas pelos nascidos em Campinas e pelos estratos mais altos de renda, escolaridade, e que ingeriam frutas e hortaliças $\geq 4$ vezes/semana. Os resultados revelam o perfil epidemiológico associado às técnicas de preparo de carnes; mulheres e idosos empregam mais calor úmido e menos fritura, e os mais favorecidos economicamente usam menos cocção úmida e fritura, e mais o assar/grelhar.

Palavras-chave Carne, Culinária, Consumo Alimentar, Inquérito Epidemiológico 


\section{Introduction}

The intake of red and processed meat should not exceed 300g a week according to the World Cancer Research Fund (WCRF) ${ }^{1}$. However, in Brazil over $80 \%$ of the population consumed meat in quantities exceeding the recommendation of the WCRF according to data from the Household Budget Survey of 2008-2009².

There is reliable evidence to support the benefits of moderate amounts of animal products in the human diet, due to its high nutritional density $^{3,4}$. However, preparation techniques may impair its nutritional contribution, either through nutrient loss or through formation of toxic compounds. The use of excess heat in meat preparation produces heterocyclic amines (HCAs) and polycyclic aromatic hydrocarbons $(\mathrm{PAHs})^{5-7}$, both with proven carcinogenic action, as well as advanced glycation end products (AGEs), also of concern'.

Meat preparation techniques that combine high temperature and low moisture conditions with protein and carbohydrate-rich ingredients increase the concentrations of AGEs. There is consequent increased risk of microvascular complications and chronic diseases such as diabetes ${ }^{9}$ and cardiovascular disease $\mathrm{e}^{10}$.

Results of epidemiological studies show an association between intake of meat with high levels of heterocyclic amines and the occurrence of neoplasms such as colorectal ${ }^{11}$, prostate ${ }^{12}$, renal parenchyma ${ }^{13}$, esophageal and gastric ${ }^{14}$.

Considering the high intake of meat, the importance of knowing the meat preparation techniques, the lack of information about the cooking methods given the economic inequalities in Brazil and the relevance of improving culinary skills for healthy meals, the objective of this study was to identify the meat preparation techniques according to sociodemographic variables and health-related behaviors.

\section{Methods}

The Campinas Health Survey (ISACamp) is a population-based cross-sectional study conducted with non-institutionalized individuals aged 10 years and older, residents of urban areas in the city of Campinas, São Paulo State, Brazil. Data was collected on a probabilistic stratified cluster sample in two stages: census-tract and household. In the first stage, 50 census-tracts were systematically drawn with a probability propor- tional to the number of households. There was address update using field work in the selected census-tracts. In the second stage there was a random selection of households. Data was collected from February 2008 to April 2009.

The sample size was determined considering the estimation of a proportion of $50 \%(\mathrm{P}=0.50)$, with $95 \%$ confidence level $(95 \% \mathrm{CI})$, a sampling error between 4 and 5\% and a design effect of 2. Independent samples were defined having a minimum size of 1,000 individuals in each age groups: adolescents (10 to 19 years), adults (20 to 59 years) and elderly (60 years or more). Assuming $80 \%$ of coverage and response rate, the sample size was corrected to 1,250 . To achieve this sample size in each age group, 2,150, $700 \mathrm{e}$ 3,900 households were randomly selected to obtain the expected number of adolescents, adults and elderly, respectively. All residents in the selected age group for the household in question were interviewed.

Information was collected through a structured questionnaire in 14 thematic sections tested in a pilot study and administered with home interviews by trained and supervised interviewers. Interviews were conducted on different days of the week, for 14 months. A 24-hour recall and a Food Frequency Questionnaire were included in the thematic section on dietary habits. There was no detailed information on the frequency of using cooking techniques to prepare meats or who was responsible for cooking at home. Then, a single 24-hour dietary recall was used to identify meat preparation techniques. A protocol to identify cooking methods was developed in an attempt to eliminate potential differences due to miscomprehension related to each culinary technique.

The variables analyzed in the present study were:

Culinary techniques: The preparation techniques were classified into two groups, according to the use of water (moist): 1) Dry-heat cooking (DH) for baking, grilling/barbecuing, and frying; 2) Moist-heat cooking (MH) for cooking methods that add water, other liquid or use steam as in stewing and boiling. Frying was analyzed separately from the other techniques of $\mathrm{DH}$ cooking (baking and grilling/barbecuing) because it is a usual form of preparation and has high sensorial acceptance.

The definitions of dry and moist heat cooking and the preparation techniques for each type of cooking were described in the protocol, namely:

- Dry-heat cooking (DH): heat treatment that causes food dehydration due to excess heat. 
○ Baking: cooking of previously seasoned foods in ovens, without lid and without addition of liquids;

- Grilling/barbecuing: food placed on a hot metal plate or grill, near the source of heat (ember, gas or electricity); includes roasting;

○ Frying: food immersed in oil at high temperature.

- Moist-heat cooking $(\mathrm{MH})$ : heat treatment using water, other liquid or steam as a heat transfer medium.

- Sauté: method which employs fat and the food's moisture as a means of heat distribution;

- Stew: consists of saute the food, adding the amount of liquid (water, juice, wine) needed to soften;

- Boil: food dipped in boiling water.

Demographic and socioeconomic variables: sex, age (in years), educational level of the household head (in years of study), household income per capita (in minimum wages), number of appliances in the household (freezer, vacuum cleaner, washing machine, air conditioning, dishwasher, computer, among others), and place of birth (city of Campinas, São Paulo; another city from the state of São Paulo, and another state).

Health-related behaviors: weekly intake of fruit and vegetables, and soft drinks, categorized in $\geq 4$ or $<4$ times/week, estimated by a Food Frequency Questionnaire.

Dietary data were analyzed using Nutrition Data System for Research (NDS-R) software (version 2007, Nutrition Coordinating Center, University of Minnesota). Data were entered following rules from the NDS-R. Quality assurance on each record was done by a dietitian with broad experience in dietary surveys.

Prevalence, adjusted prevalence ratios and 95\% confidence intervals were estimated for each meat cooking method according to demographic, socioeconomic and health-related behaviors. The prevalence ratios were adjusted for age and sex. The chi-square test and linear trends were used to compare differences in prevalence, considering a significance level of $5 \%(p<0.05)$. Statistical analysis was conducted using the survey (svy) module in Stata 11.0 (Stata Corp., College Station, USA).

The project ISACamp 2008-2009 was approved by the Research Ethics Committee of the School of Medical Sciences at the University of Campinas.

\section{Results}

A total of 3,376 subjects were analyzed: 922 adolescents, 950 adults and 1,504 elderly. The mean age was 14.2 years (95\%CI: 13.9-14.5) for teenagers, 36.8 years (95\%CI: 35.8-37.8) for adults and 69.6 years (95\%CI: 68.9-70.3) for the elderly. Women represented $51.7 \%$ of the sample and those born in Campinas, 44.6\%; subjects with a per capita family income lower than a minimum wage represent $42.8 \%$ and those with educational level (head of household) less than 8 years were $40.5 \%$. Near $82.0 \%$ of the subjects had regular intake of fruits and vegetables more than 4 times/ week, and 69.3\% consumed sugary drinks less than 4 times/week (Table 1).

Table 2 shows that $39.0 \%$ of participants used $\mathrm{MH}$ cooking techniques. It was more likely to be used among women, older people and those from other municipalities or states. Those with lower level of education ( $<8$ years, $43.8 \%$ ), lower family income ( $\leq 1$ minimum wage, $42.9 \%$ ) and those who lived in a house with seven or less household appliances $(49.7 \%)$ were also more likely to use $\mathrm{MH}$ cooking.

Among the techniques that employ high temperature and low humidity (Table 3), classified as DH cooking, 32.7\% used deep frying to cook meats. Frying was less used by women, the elderly, and persons of higher education and income. Near $28.0 \%$ of the participants used other DH techniques such as roasting and grilling. DH techniques were the most common methods for those born in Campinas and among those of higher educational level, family income, number of household appliances and those who ate fruits and vegetables four or more times a week (Table 3).

\section{Discussion}

This study provides information related to meat preparation techniques according to sociodemographic variables and health-related behaviors. To our knowledge, there is no other population-based study describing the prevalence of meat culinary techniques in Brazil.

The form of food preparation is determined by the nature of the food matrix, the preference and sensory quality of products, as well as the resources available such as tools, equipment and sources of energy for cooking. For this reason, the cooking methods will vary in terms of cooking time, heating rate and percentage of loss. There 
Table 1. Sample distribution according to demographic and socioeconomic variables, and health-related behaviors. Health survey of the city of Campinas (ISACamp 2008-09).

\begin{tabular}{|c|c|c|c|}
\hline Variables & $\mathbf{n}^{*}$ & $\%^{\star *}$ & 95\%CI \\
\hline \multicolumn{4}{|l|}{ Sex } \\
\hline Male & 1,522 & 48.3 & $46.2-50.4$ \\
\hline Female & 1,854 & 51.7 & $49.6-53.8$ \\
\hline \multicolumn{4}{|l|}{ Age group } \\
\hline Adolescent & 922 & 17.1 & $15.3-19.0$ \\
\hline Adult & 950 & 69.6 & $67.2-71.8$ \\
\hline Elderly & 1,504 & 13.3 & $11.4-15.3$ \\
\hline \multicolumn{4}{|l|}{ Place of birth } \\
\hline Campinas & 1,399 & 44.6 & $39.9-49.2$ \\
\hline $\begin{array}{l}\text { Another city from the } \\
\text { state of SP }\end{array}$ & 1,057 & 27.4 & $24.2-30.6$ \\
\hline Another state & 917 & 28.0 & $23.4-32.7$ \\
\hline \multicolumn{4}{|l|}{$\begin{array}{l}\text { Education of the household } \\
\text { head (years) }\end{array}$} \\
\hline 0 to 7 & 1,649 & 40.5 & $32.9-48.0$ \\
\hline 8 to 11 & 938 & 32.8 & $28.3-37.3$ \\
\hline 12 or + & 767 & 26.7 & 18.1-35.4 \\
\hline \multicolumn{4}{|l|}{$\begin{array}{l}\text { Monthly income per capita } \\
(\mathrm{MW})^{* * *}\end{array}$} \\
\hline$\leq 1$ & 1,559 & 42.8 & $35.6-50.0$ \\
\hline$>1$ to $\leq 3$ & 1,284 & 39.2 & $33.2-45.2$ \\
\hline$>3$ & 533 & 18.0 & $11.0-24.9$ \\
\hline \multicolumn{4}{|l|}{$\begin{array}{l}\text { \# of appliances in the } \\
\text { household }\end{array}$} \\
\hline 1 to 7 & 998 & 25.5 & $18.3-32.8$ \\
\hline 8 to 13 & 1,343 & 39.1 & $34.5-43.8$ \\
\hline 14 or + & 1,032 & 35.3 & $27.1-43.5$ \\
\hline \multicolumn{4}{|l|}{$\begin{array}{l}\text { Weekly consumption of } \\
\text { soft drinks }\end{array}$} \\
\hline$\geq 4$ times & 932 & 30.6 & $27.6-33.7$ \\
\hline$<4$ times & 2,443 & 69.3 & $66.3-72.4$ \\
\hline \multicolumn{4}{|l|}{$\begin{array}{l}\text { Weekly consumption of } \\
\text { F\&V }\end{array}$} \\
\hline$\geq 4$ times & 2,819 & 81.7 & $78.8-84.6$ \\
\hline$<4$ times & 556 & 18.3 & $15.4-21.2$ \\
\hline
\end{tabular}

is some difficulty to combine these parameters to accurately identify the preparation technique and thus establish a comparison between studies conducted in different countries ${ }^{15,16}$.

Despite the gap in the literature on standardized procedures, to avoid discrepancies between the identity of cooking methods it is possible to group them according to general characteristics such as the use of liquid as a means of cooking - moist-heat cooking and dry-heat cooking,
Table 2. Prevalence and adjusted prevalence ratios (PR) of moist-heat cooking according to demographic and socioeconomic variables, and health-related behaviors. Health survey of the city of Campinas (ISACamp 2008-09).

\begin{tabular}{|c|c|c|}
\hline \multirow{2}{*}{ Variables } & \multicolumn{2}{|c|}{ Moist heat cooking } \\
\hline & $\%$ & $\mathrm{PR}^{\mathrm{a}}(\mathbf{9 5 \% C I )}$ \\
\hline Sex & $0.002^{\star}$ & \\
\hline Male & 36.1 & 1.00 \\
\hline Female & 42.1 & $1.04(1.02-1.07)$ \\
\hline Total & 39.0 & \\
\hline Age group & $<0.001^{\star *}$ & \\
\hline Adolescent & 37.3 & 1.00 \\
\hline Adult & 38.5 & $1.01(0.98-1.04)$ \\
\hline Elderly & 45.1 & $1.05(1.03-1.08)$ \\
\hline Place of birth & $<0.001^{\star}$ & \\
\hline Campinas & 33.7 & 1.00 \\
\hline $\begin{array}{l}\text { Another city from } \\
\text { the state of SP }\end{array}$ & 43.8 & $1.08(1.04-1.12)$ \\
\hline Another state & 43.3 & $1.07(1.03-1.12)$ \\
\hline $\begin{array}{l}\text { Education of the } \\
\text { household head (years) }\end{array}$ & $0.004^{*}$ & \\
\hline 0 to 7 & 43.8 & 1.00 \\
\hline 8 to 11 & 35.2 & $0.94(0.90-0.98)$ \\
\hline 12 or + & 36.7 & $0.95(0.91-0.99)$ \\
\hline $\begin{array}{l}\text { Monthly income per } \\
\text { capita }(\mathrm{MW})^{\star * *}\end{array}$ & $0.064^{*}$ & \\
\hline$\leq 1$ & 42.9 & 1.00 \\
\hline$>1$ to $\leq 3$ & 36.3 & $0.95(0.91-0.99)$ \\
\hline$>3$ & 36.6 & $0.95(0.90-1.01)$ \\
\hline $\begin{array}{l}\text { \# of appliances in the } \\
\text { household }\end{array}$ & $<0.001^{\star *}$ & \\
\hline 1 to 7 & 49.7 & 1.00 \\
\hline 8 to 13 & 37.1 & $0.92(0.88-0.96)$ \\
\hline 14 or + & 34.4 & $0.90(0.85-0.95)$ \\
\hline $\begin{array}{l}\text { Weekly consumption } \\
\text { of soft drinks }\end{array}$ & $0.977^{\star}$ & \\
\hline$\geq 4$ times & 39.1 & $1.01(0.97-1.05)$ \\
\hline$<4$ times & 39.1 & 1.00 \\
\hline $\begin{array}{l}\text { Weekly consumption } \\
\text { of F\&V }\end{array}$ & $0.329^{*}$ & \\
\hline$\geq 4$ times & 38.6 & $0.97(0.93-1.01)$ \\
\hline$<4$ times & 41.3 & 1.00 \\
\hline
\end{tabular}

which cause similar effects on the food matrix, regardless of the type of tool or apparatus used for cooking, typical of each culinary culture.

Studies on culinary skills and confidence to cook show that less time has been devoted to the preparation of food ${ }^{15}$, and that the consumption of animal products has been the subject of 
Table 3. Prevalence and adjusted prevalence ratios (PR) of dry-heat cooking according to demographic and socioeconomic variables, and health-related behaviors. Health survey of the city of Campinas (ISACamp 200809).

\begin{tabular}{|c|c|c|c|c|}
\hline \multirow{2}{*}{ Variables } & \multicolumn{2}{|c|}{ Frying } & \multicolumn{2}{|c|}{ Other dry-heat } \\
\hline & $\%$ & $\mathrm{PR}^{\mathrm{a}}(\mathbf{9 5 \% C I )}$ & $\%$ & $\mathrm{PR}^{\mathrm{a}}(\mathbf{9 5 \% \mathrm { CI } )}$ \\
\hline Sex & $0.032^{\star}$ & & $0.127^{\star}$ & \\
\hline Male & 34.4 & 1.00 & 29.5 & 1.00 \\
\hline Female & 31.0 & $0.97(0.95-0.99)$ & 26.9 & $0.98(0.95-1.01)$ \\
\hline Total & 32.7 & & 28.3 & \\
\hline Age group & $0.035^{\star \star}$ & & $0.088^{\star}$ & \\
\hline Adolescent & 35.9 & 1.00 & 26.8 & 1.00 \\
\hline Adult & 32.3 & $0.97(0.94-1.01)$ & 29.2 & $1.02(0.99-1.05)$ \\
\hline Elderly & 30.3 & $0.96(0.93-0.99)$ & 24.6 & $0.98(0.95-1.02)$ \\
\hline Place of birth & $0.380^{*}$ & & $0.027^{\star *}$ & \\
\hline Campinas & 34.5 & 1.00 & 31.8 & 1.00 \\
\hline Another city from the state of SP & 30.3 & $0.97(0.93-1.01)$ & 25.9 & $0.95(0.90-0.99)$ \\
\hline Another state & 31.9 & $0.99(0.93-1.04)$ & 24.8 & $0.94(0.90-0.98)$ \\
\hline Education of the household head (years) & $0.006^{\star *}$ & & $<0.001^{\star *}$ & \\
\hline 0 to 7 & 37.0 & 1.00 & 19.1 & 1.00 \\
\hline 8 to 11 & 32.7 & $0.96(0.92-1.01)$ & 32.1 & $1.11(1.05-1.16)$ \\
\hline 12 or + & 26.4 & $0.92(0.88-0.97)$ & 36.9 & $1.15(1.09-1.20)$ \\
\hline Monthly income per capita $(\mathrm{MW})^{\star \star \star}$ & $0.014^{\star *}$ & & $<0.001^{\star *}$ & \\
\hline$\leq 1$ & 34.7 & 1.00 & 22.4 & 1.00 \\
\hline$>1$ to $\leq 3$ & 34.1 & $1.00(0.95-1.04)$ & 29.6 & $1.06(1.01-1.11)$ \\
\hline$>3$ & 25.0 & $0.93(0.88-0.98)$ & 38.4 & $1.13(1.07-1.19)$ \\
\hline \# of appliances in the household & $0.008^{*}$ & & $<0.001^{\star *}$ & \\
\hline 1 to 7 & 31.3 & 1.00 & 19.0 & 1.00 \\
\hline 8 to 13 & 37.5 & $1.04(0.99-1.10)$ & 25.4 & $1.05(1.00-1.11)$ \\
\hline 14 or + & 28.6 & $0.97(0.93-1.02)$ & 37.0 & $1.15(1.09-1.21)$ \\
\hline Weekly consumption of soft drinks & $0.508^{*}$ & & $0.582^{\star}$ & \\
\hline$\geq 4$ times & 31.5 & $0.98(0.94-1.02)$ & 29.4 & $1.01(0.96-1.06)$ \\
\hline$<4$ times & 33.1 & 1.00 & 27.8 & 1.00 \\
\hline Weekly consumption of F\&V & $0.092^{*}$ & & $0.008^{\star}$ & \\
\hline$\geq 4$ times & 31.7 & $0.97(0.93-1.01)$ & 29.7 & $1.06(1.02-1.10)$ \\
\hline$<4$ times & 36.3 & 1.00 & 22.4 & 1.00 \\
\hline
\end{tabular}

countermessages or demarketing that have influences on health beliefs and practices ${ }^{16}$. Grilled or fried meat cuts require less preparation time compared to those cooked in liquid, which may explain at least in part the preference for $\mathrm{DH}$ as a cooking method. The sensory characteristics produced by $\mathrm{DH}$ are another possible reason for the popularity of this meat preparation technique ${ }^{17}$.

In the $\mathrm{DH}$, the production of HCAs, such that PhIP (2-amino-1-methyl1-6-phenylimidazo[4,5-b]pyridine) is more common, especially when employing deep frying ${ }^{18}$. In Brazil, it has been shown that the intake of HCAs through meat prepared by $\mathrm{DH}$ is associated with increased malondialdehyde (MDA), an important marker of oxidative stress ${ }^{19}$. Evidence indicates that the preparation techniques that employ high temperature and low moisture content with high production of HCAs, have an association with esophageal ${ }^{14}$, prostate ${ }^{12,20}$, kidney ${ }^{13}$ and colorectal cancers $^{11}$. High levels of HCAs were associated with greater cognitive decline in the elderly after nine years of follow-up ${ }^{21}$.

Recently, the message received from the World Health Organization on the association between red and processed meat intake and cancer of various locations ${ }^{1}$ has received a lot of attention. The search for forms of preparation that save time in the kitchen can be a cause of the high prevalence of deep frying compared to other techniques. 
The results found in this study reveal a sociodemographic profile associated to meat preparation techniques. MH was more used by women, the elderly and people of low socioeconomic level; it is noteworthy that DH techniques are associated with the use of more appliances and rising expenses with frying oil. Frying was more used by men, adolescents and by individuals with lower levels of income and schooling. Other DH techniques, such as roasting, grilling and barbecuing, were shown to be associated with the most economically favored segments and those who ate more fruits and vegetables. Meat cuts rich in connective tissue (e.g., shank) are cheaper and require the use of moist cooking for collagen hydrolysis and meat tenderization. Brazilian's traditional food is based on rice and beans, which represent almost a quarter of the food, followed by red meats and chicken ${ }^{22}$. In a qualitative research, Garcia $^{23}$ verified that the economic condition of the families determined the choice, the variety of meat cuts and the amount distributed among the relatives.

The result that the elderly eat more cooked meats can be explained by problems related to the difficulty of chewing and digestion, which are common alterations in this life stage ${ }^{24}$. The lower consumption of fried food among women can be attributed to a number of factors, including greater concern about the quality of food and weight gain ${ }^{25,26}$. The segments with the best socioeconomic level present a healthier food behavior, characterized by higher intakes of fruits, vegetables, whole grains and lean meats ${ }^{26-28}$. Also, it is widely reported by the media and health professionals that frying is harmful to health and that roasting and grilling are healthier because they use little or no oil, a probable source of misconceptions about healthy-cooking.

In this study we demonstrated that $\mathrm{DH}$ was the most prevalent form of meat preparation, especially deep frying; $\mathrm{MH}$, which was less prevalent than $\mathrm{DH}$, protects the food matrix from the risk of forming compounds that promote oxidative stress and inflammation, such as AGEs ${ }^{8}$, and for this reason should be encouraged in messages for the promotion of healthy eating. The formation of AGEs can be reduced by using less heat- ing time, low temperature, high humidity and/or acidic marinades with spices, vinegar or lemon juice before cooking the meat ${ }^{8}$.

The results of this study imply public health actions aimed at informing the population about the safe preparation of meat, with time and temperature control; that the use of DH methods such as roasting, grilling and frying presents a greater risk for the formation of carcinogenic compounds; and that $\mathrm{MH}$ cooking, by maintaining moderate heat (between $100^{\circ} \mathrm{C}$ and $120^{\circ} \mathrm{C}$ ) is the safest way to prepare meat. Guidance on cooking techniques can be incorporated into dietary guidelines and combined with recommendations for meat consumption.

New approaches for the risk assessment relating diet and disease should recognize dry heat as a cause of producing toxic compounds in food; thus, including research of the type of food preparation technique in dietary surveys can help to identify new risk factors from food with explanatory power associated to chronic diseases ${ }^{29-31}$.

Among the limitations of this study, it is highlighted that the application of a single 24-hour recall does not represent the individual's usual intake due to the intraindividual variability of food intake ${ }^{32}$. However, when applied on a population basis and in order to consider the different days and months of the year, it is possible to estimate the average intake for the target population with only one 24 -hour recall ${ }^{33}$. It is important to note that the cross-sectional study impedes interpreting the associations found as resulting from a cause and effect relationship. The data used in this study come from a health survey that covers a wide range of topics, but has identified food consumption issues that have attracted attention and which suggest new research approaches, such as the inclusion of culinary techniques among the variables of interest in dietary surveys.

This study offers some evidence regarding the importance to identify meat culinary techniques as an auxiliary information for the improvement of dietary survey analysis. The data also indicate that one should consider the differences of sex, given that men, who traditionally have lower confidence to cook than women, consume more meat prepared by $\mathrm{DH}$ than women. 


\section{Collaborations}

D Assumpção conducted a revision of the literature in this area as well as having analyzed the data and drafted the text. MBA Barros and RM Fisberg collaborated in interpreting the data as well as drafting and critically revising the intellectual content. SMA Domene came up with the proposal for this paper as well as analyzing the data and drafting the text.

\section{References}

1. Bouvard V, Loomis D, Guyton KZ, Grosse Y, El Ghissassi F, Benbrahim-Tallaa L, Guha N, Mattock H, Straif K, International Agency for Research on Cancer Monograph Working Group. Carcinogenicity of consumption of red and processed meat. Lancet Oncology 2015; 16(16):1599-1600.

2. Carvalho AM, Selem SS, Miranda AM, Marchioni DM. Excessive red and processed meat intake: relations with health and environment in Brazil. Br J Nutr 2016; 115(11):2011-2016.

3. Pereira PM, Vicente AF. Meat nutritional composition and nutritive role in the human diet. Meat Sci 2013; 93(3):586-592.

4. Zanovec M, O'Neil CE, Keast DR, Fulgoni VL, Nicklas TA. Lean beef contributes significant amounts of key nutrients to the diets of US adults: National Health and Nutrition Examination Survey 1999-2004. Nutr Res 2010; 30(6):375-381.

5. Sinha R, Rothman N, Salmon CP, Knize MG, Brown ED, Swanson CA, Rhodes D, Rossi S, Felton JS, Levander OA. Heterocyclic Amine Content in Beef Cooked by Different Methods to Varying Degrees of Doneness and Gravy made from Meat Drippings. Food Chem Toxicol 1998; 36(4):279-287.

6. Keating GA, Layton DW, Felton JS. Factors determining dietary intakes of heterocyclic amines in cooked foods. Mutat Res 1999; 443(1-2):149-156.

7. Kikugawa K. Prevention of mutagen formation in heated meats and model systems. Mutagenesis 2004; 19(6):431-439.

8. Uribarri J, Woodruff S, Goodman S, Cai W, Chen X, Pyzik R, Yong A, Striker GE, Vlassara H. Advanced glycation end products in foods and a practical guide to their reduction in the diet. J Am Diet Assoc 2010; 110(6):911-916.

9. Singh VP, Bali A, Singh N, Jaggi AS. Advanced Glycation End Products and Diabetic Complications. Korean J Physiol Pharmacol 2014; 18(1):1-14.

10. Hegab Z, Gibbons S, Neyses L, Mamas MA. Role of advanced glycation end products in cardiovascular disease. World J Cardiol 2012; 4(4):90-102.

11. Sinha R, Peters U, Cross AJ, Kulldorff M, Weissfeld JL, Pinsky PF. Meat, meat cooking methods and preservation, and risk for colorectal adenoma. Cancer Res 2005; 65(17):8034-8041.

12. Cross AJ, Peters U, Kirsh VA, Andriole GL, Reding D, Hayes RB, Sinha R. A Prospective Study of Meat and Meat Mutagens and Prostate Cancer Risk. Cancer Res 2005; 65(24):11779-11784.

13. Daniel CR, Cross AJ, Graubard BI, Park Y, Ward MH, Rothman N, Hollenbeck AR, Chow WH, Sinha R. Large prospective investigation of meat intake, related mutagens, and risk of renal cell carcinoma. Am J Clin Nutr 2012; 95(1):155-162.

14. Cross AJ, Freedman ND, Ren J, Ward MH, Hollenbeck AR, Schatzkin A, Sinha R, Abnet CC. Meat consumption and risk of esophageal and gastric cancer in a large prospective study. Am J Gastroenterol 2011; 106(3):432-442. 
15. Gatley A, Caraher M, Lang T. A qualitative, cross cultural examination of attitudes and behaviour in relation to cooking habits in France and Britain. Appetite 2014; 75:71-81.

16. Gittelsohn J, Vastine AE. Sociocultural and Household Factors Impacting on the Selection, Allocation and Consumption of Animal Source Foods: Current Knowledge and Application. J. Nutr 2003; $133(11$ Supl. 2):4036S-4041S.

17. Choe E, Min DB. Chemistry of deep-fat frying oils. $J$ Food Sci 2007; 72(5):77-86.

18. Puangsombat K, Gadgil P, Houser TA, Hunt MC, Smith JS. Occurrence of heterocyclic amines in cooked meat products. Meat Science 2012; 90(3):739746.

19. Carvalho AM, Miranda AM, Santos FA, Loureiro AP, Fisberg RM, Marchioni DM. High intake of heterocyclic amines from meat is associated with oxidative stress. Br J Nutr 2015; 113(8):1301-1307.

20. Sinha R, Park Y, Graubard BI, Leitzmann MF, Hollenbeck A, Schatzkin A, Cross AJ. Meat and meat-related compounds and risk of prostate cancer in a large prospective cohort study in the United States. Am J Epidemiol 2009; 170(9):1165-1177.

21. Yaffe K, Lindquist K, Schwartz AV, Vitartas C, Vittinghoff E, Satterfield S, Simonsick EM, Launer L, Rosano C, Cauley JA, Harris T. Advanced glycation end product level, diabetes, and accelerated cognitive aging. Neurology 2011; 77(14):1351-1356.

22. Brasil. Ministério da Saúde (MS). Secretaria de Atenção à Saúde. Departamento de Atenção Básica. Guia Alimentar para a População Brasileira. Brasília: MS; 2014.

23. Garcia RWD. Representações sobre consumo alimentar e suas implicações em inquéritos alimentares: estudo qualitativo em sujeitos submetidos à prescrição dietética. Rev Nutr 2004; 17(1):15-28.

24. Clifford J, Bellows L. Nutrition and Aging. Colorado: Colorado State University; 2015.

25. Assumpção D, Domene SMA, Fisberg RM, Canesqui AM, Barros MBA. Diferenças entre homens e mulheres na qualidade da dieta: estudo de base populacional em Campinas, São Paulo. Cien Saude Colet 2017; 22(2):347-358.

26. Imamura F, Micha R, Khatibzadeh S, Fahimi S, Shi P, Powles J, Mozaffarian D, Global Burden of Diseases Nutrition and Chronic Diseases Expert Group (NutriCoDE). Dietary quality among men and women in 187 countries in 1990 and 2010: a systematic assessment. Lancet Glob Health 2015; 3(3):e132-e142.
27. Levy RB, Claro RM, Mondini L, Sichieri R, Monteiro CA. Distribuição regional e socioeconômica da disponibilidade domiciliar de alimentos no Brasil em 20082009. Rev Saúde Pública 2012; 46(1):6-15.

28. Assumpção D, Domene SMA, Fisberg RM, Barros MBA. Social and demographic inequalities in diet quality in a population-based study. Rev Nutr 2016; 29(2):151-162.

29. Wang H, Iwasaki M, Haiman CA, Kono S, Wilkens LR, Keku TO, Berndt SI, Tsugane S, Le Marchand L. Interaction between Red Meat Intake and NAT2 Genotype in Increasing the Risk of Colorectal Cancer in Japanese and African Americans. PLoS ONE 2015; 10(12):e0144955.

30. Melkonian SC, Daniel CR, Ye Y, Tannir NM, Karam JA, Matin SF, Wood CG, Wu X. Gene-Environment Interaction of Genome-Wide Association Study-Identified Susceptibility Loci and Meat-Cooking Mutagens in the Etiology of Renal Cell Carcinoma. Cancer 2016; 122(1):108-115.

31. 31. Andersen V, Vogel U. Interactions between meat intake and genetic variation in relation to colorectal cancer. Genes Nutr 2015; 10:448.

32. 32. Domene SMA. Avaliação do consumo alimentar. In: Taddei JA, Lang RMF, Silva GL, Toloni MHA, editores. Nutrição em Saúde Pública. Rio de Janeiro: Rubio; 2011. p. 41-54.

33. 33. Breslow RA, Guenther PM, Juan W, Graubard BI. Alcoholic beverage consumption, nutrient intakes, and diet quality in the US adult population, 19992006. J Am Diet Assoc 2010; 110(4):551-562.

Article submitted 30/12/2016

Approved 05/09/2018

Final version submitted 07/09/2018 